\title{
A Review : On Phytochemical Analysis and Antioxidant activities with Medicinal uses of Combretaceae Family
}

\author{
Christian Stacey*1, Bharat Maitreya ${ }^{2}$ \\ ${ }^{*}$ Department of Botany, Bioinformatics \& Climate Change Impacts Management, USSC, Gujarat University, \\ Ahmedabad, Gujarat, India \\ ${ }^{2}$ Department of Botany, Bioinformatics \& Climate Change Impacts Management, USSC, Gujarat University, \\ Ahmedabad, Gujarat, India
}

\begin{abstract}
Article Info

Volume 8, Issue 2

Page Number : 287-294

Publication Issue

March-April-2021

Article History

Accepted : 01 April 2021

Published : 03 April 2021

The Combretaceae family consists of 600 species of trees, shrubs and lianas in about 18-20 genera. Plants belonging to this family are found in tropical and subtropical regions, mostly in Africa and India. Combretum and Terminalia are the largest and most widespread genus of Combretaceae. Species of Combretaceae family are reported for treating many diseases and have important secondary metabolites with antioxidant activities. This review focuses on 11 medicinal plants, 9 phytochemical containing plants and 33 plants having antioxidant activity.

Keywords : Phytochemical Analysis, Antioxidant Activity, Medicinal Uses and Combretaceae Family.
\end{abstract}

\section{INTRODUCTION}

In recent years, plants have received attentions as its derived products have pharmacological properties which includes antioxidant, antimicrobial and antitumour activities (Karthikumar et al., 2007). Plant produces rang of bioactive molecules which have probably evolved as chemical defence against predation or infection (Mangoyi $\mathrm{R}$ et al., 2012). Bioactive chemical substance that are produced by plants have definite biochemical and physiological actions on human body which are alkaloids, flavonoids, tannins, phenolic compounds etc (Hills, 1952; Cho et al., 2004; Edeoga et al., 2005). Plant parts like root, stem, leaf, fruit, seed, flowers,tuber, buds, rhizomes, etc which are having many medicinal uses which are helpful for treating many diseases. M.A. Aderogba and others in 2012 stated that many species of family Combretaceae have extensively used in traditional medicines against infections and inflammation, and although its antibacterial, antifungal, antitumor and antioxidant activities have been reported. It is also used by many cultures in folk medicines for the treatment of microbial infections and several inflammatory diseases such as abdominal pains, toothache and headache (Eloff et al., 2001; Hutchings et al., 1996). 


\section{MEDICINAL USES}

Medicinal plants have tremendous alternative remedies which are used worldwide to prevent and treat infectious diseases (Bokhad M. N et al., 2012; Soulsby EJ., 2005). It is very important source for the development of novel chemotherapeutic agents (G.Shivapriya et al., 2019). Umar et al., 2007 reported that $50 \%$ of natural products represents all drugs in clinical uses, with $25 \%$ of the total representing higher plant derived natural products. Many different cultures in folklore record lead to useful medicinal properties in plants (G.Shivapriya et al., 2019).

Several compounds have been isolated from species of Combretaceae family including flavonoids, phenanthrenes, stilbenes, cyclobutanes and triterpenoids which are widely spread in the tropical climes of Africa, South America and Asia. Its species are important in traditional medicinal practice and some of them are used for treating syphilis, abdomen pains, toothache, diarrhoea, conjunctivitis and other alimentary problems Masoko P et al.,2006; Martini ND et al., 2004.

Kerharo et al., 1950 reported that Combretum zenkeri is used for treating dysentery which contains appreciable level of alkaloid and flavonoid (C. O. Ujowundu et al.,2010) which have been used to treat diuretic, anti-inflammatory, antispasmodic and analgesic effects, (Owoyele et al., 2002) and it is used externally and internally for the treatment of certain disorders like diarrhoea, Oedemas, fungal infection, dropsy, gout and swellings (Bouquet et al., 1974).

Thomas (1974) reported that leaves of this plant is used by Igbos in worm-treatment.

Eloff, 1999b; Eloff et al., 2006; Martini et al., 1998; McGaw et al., 2001 have confirmed many species of Combretum having antimicrobial activity. In Combretum apiculatum, Serage in 2003 reported that it includes pinocembrin, alpinetine and flavokawain which acts as antimicrobial compounds. Combretum zeyheri Sond, Combretum apiculatum Sond, Combretum molle Engl. and Diels, Combretum kraussii Hochst, Combretum elaegnoides Klotzsch and Combretum imberbe Wawra were studied by Mangoyi R and others in 2011 for their antifungal properties and used as Zimbabwe traditional medicine. Combretum mole is used to treat fever and stomach complaints by Engl. And Diels (Mangoyi R et al., 2012). Combretum imberbe Wawra is used to cure cough, cold, diarrhoea and Combretum apiculatum Sond can treat bites of scorpion and snake, leprosy, bloody diarrhoea, conjunctivities, abdominal disorder and weak body (Rogers et al., 1996). Combretum zeyheri Sond can cure the bites of snake and can cure coughs, diarrhoea, stomachache and rectal prolapse (Ruffo et al.,1991). Mangoyi R et al., 2012 reported Combretum kraussii Hochst is used as antidiuretics, lotions for eye infections as well as antiseptics. Terminalia ivorensis, of Combretaceae family plant, is widely used traditional medicinal to treat dermal diseases and also having antibacterial substances contained in the trunk barks of Terminalia ivorensis (Coulibaly $\mathrm{k}$ et al., 2014). Buchenavia tetraphylla have antimicrobial activity, as described in the section on quinones, may be related to their ability to inactivate microbial adhesins, enzymes, cell envelope transport proteins, and so forth by M.M. Cowan in 1999. A. Mann et al., 2008 obtained in his study that showed the ethanolic extracts of stem bark, root bark and leaves of Terminalia avicennioides has antimicrobial activities on test organisms used in this study and also concluded that it acts against the clinical isolates of complicated respiratory tract infectious diseases in Niger state, Nigeria. The leaves of the Combretum glutinosum plant are used to treat diseases like malaria, anorexia, anemia, cough, bronchitis, fever, diarrhea, liver disease and liver failure and to combat microbial agents (Kerharo et al., 1974; Nacoulma et al., 1996). The leaves or stembark are crushed and used for dressing wounds (Bukill, 
2000; PROTA 3, 2005). Anogeissus leiocarpus is a tree that is considered to be sacred and used for treating diseases. The decoction and maceration of the stem bark are used against constipation, malaria, jaundice, eczema, itching, anorexia, wounds, carbuncles, psoriasis, boils and various forms of ulcers and the decoction of the leaves is used in amoebic dysentery, various forms of hepatitis and treatment of jaundice (Kerharo et al., 1974, Nacoulma et al., 1996).

\section{PHYTOCHEMICAL ANALYSIS}

Bokhad M. N et al., 2012 studied about Combretum albidum. He carried out preliminary phytochemical analysis using six solvents according to the polarity that are Benzene, chloroform, acetone, ethanol, petroleum ether and water respectively by Soxhlet method for 18 hours. He used standard procedure for identification of its constituents, as describe by Harborne et al., 1984, Trease et al., 1979. The preliminary Phytochemical screening of leaf, stem, flower and fruit shows that there is presence of alkaloid, carbohydrate, proteins, cardiacglycoside, coumarin, tannin, flavonoid and phenolics compound and from these coumarin was present in all parts of plant which is very important to treat several anticoagulants. Bokhad M. N et al., 2012 had concluded that presence of this compounds in Combretum albidium G.Don would use to treat diseases which are associated with the heart, anticoagulant, anti-inflammatory action, dysentery and diarrhea. G. Shivapriya in 2019 studied about in vitro cytotoxic activity of methanolic extract of Combretum ovalifolium against MCF7 Cancer cell lines and in that study, he had done phytochemical analysis of Combretum ovalifolium. Qualitative chemical test was performed to detect glycosides, alkaloids, glycosides, saponins, phenolics, terpenoids and flavonoids (Horbone et al.,1973). It showed absence of saponins in leaf extract of methanol. Further Quantitative phytochemical analysis of phenolic content of methanol extract shows
$0.308 \mathrm{mg} / \mathrm{g}$ and flavonoid content of methanol extract shows $0.08 \mathrm{mg} / \mathrm{g}$ in leaves of Combretum ovalifolium. Result of this study showed that it had significant radical scavenging activity which is co related to their scavenging effect.

Rumbidzai Mangoyi et al., 2012 studied about Antifungal Activities and Preliminary Phytochemical Investigation of Combretum Species from Zimbabwe which is Combretum zeyheri extract was subjected to various phytochemical test as described by Kaur et al., 2009. The result showed the presence of Saponins, flavonoids, alkaloids, tannins and cardiac glycosides from which flavonoid was found to have antifungal and antimicrobial activity Aliyu AB et al., 2008.

Quantitatively determined of alkaloid was done according to the method of Harborne (2005), saponins was done according to Obadoni BO et al., 2001 and determination of tannin content was performed according to the method of Burden JPV et al., 1969. Percentage yield extract of alkaloid is 1.08 , saponin is 0.8 and tannin is 21.5 respectively.

C. O. Ujowundu in 2010 studied about Phytochemical and chemical composition of Combretum zenkeri leaves. Studies on the phytochemical, mineral, proximate and vitamin content of the leaves of Combretum zenkeri were carried out. The quantitative phytochemical composition shows that it contains $7.90 \pm 0.10 \mathrm{mg} / 100 \mathrm{~g}$ alkaloid, $10.5 \pm 1.31$ $\mathrm{mg} / 100 \mathrm{~g}$ saponin, $4.2 \pm 0.10 \mathrm{mg} / 100 \mathrm{~g}$ flavonoid, $20.088 \pm 0.91 \mathrm{mg} / 100 \mathrm{~g}$ cyanogenic glycosides and $31.86 \pm 2.10 \mathrm{mg} / 100 \mathrm{~g}$ tannin. The macro and microminerals obtained includes; $11.477 \pm 3.129 \mathrm{mg} / 100 \mathrm{~g}$ calcium , $0.0388 \pm 0.953 \mathrm{mg} / 100 \mathrm{~g}$ magnesium, $0.621 \pm$ $0.274 \mathrm{mg} / 100 \mathrm{~g}$ phosphorous, $17.500 \pm 1.44 \mathrm{mg} / 100 \mathrm{~g}$ potassium, $0.0083 \pm 0.06 \mathrm{mg} / 100 \mathrm{~g}$ iron, $0.008 \pm 0.007$ $\mathrm{mg} / 100 \mathrm{~g}$ zinc, $0.275 \pm 0.086 \mathrm{mg} / 100 \mathrm{~g}$ selenium , $0.047 \pm 0.016 \mathrm{mg} / 100 \mathrm{~g}$ manganese and $2.000 \pm 1.414$ $\mathrm{mg} / 100 \mathrm{~g}$ sodium. Vitamin A, $9.51 \pm 0.11 \mathrm{mg} / 100 \mathrm{~g}$ and ascorbic acid was $28.48 \pm 0.85 \mathrm{mg} / 100 \mathrm{~g}$. This 
study revealed that Combretum zenkeri is a very good source of phytochemical, minerals, vitamins and macronutrients which is used in medicinal and chemoprotective benefits and serve as a good source of nutrients.

Coulibaly $\mathrm{k}$ et al., 2014 studied Antibacterial properties studies of trunk barks of Terminalia ivorensis (Combretaceae), a commercial and medicinal specie, on some methicillin-resistant Staphylococci spp strains. It is woody species and phytochemical analysis was carried on bark which indicates traces of alkaloid, presence of saponins, tannins, flavonoids, sterols or terpens, polyphenols and coumarins. Results are found good in $70 \%$ ethanol as compared to the $70 \%$ of water. These classes of secondary metabolites are known to possess antibacterial activities by Cowan in 1999. Ygor Lucena Cabral de Oliveira et al., 2012 reported in Antimicrobial Activity and Phytochemical Screening of Buchenavia tetraphylla (Aubl.) R. A. Howard (Combretaceae: Combretoideae) about phytochemical analysis that shows presence of flavonoids, saponins, saponins, anthocyanins, quinones, anthraquinones, coumarins, alkaloids and reducers compounds which was done according to the method of Kokate (1994) and Harborne (1998). A. Mann et al., 2008 studied phytochemical analysis of Terminalia avicenni and had followed method describe by Harborne (1998); Evans (1989) and Sofowora (1993).

Bioactive ingredients such as alkaloids, saponins, tannins, phenols, steroids and glycosides were detected in most of the plant parts tested but anthraquinone was not detected in any of the plant extracts. SORE Harouna et al., 2012 studied about two species of family Combretaceae found in Burkina Faso they are Anogeissus Leiocarpus (DC) Guill. and Perr. and Combretum Glutinosum Perr. Ex DC. According to the method of Ciulei (1982) phytochemicals which are tannins, flavonoids, alkaloids, coumarins, saponins, sterols and triterpenes were screened. In the methanol extracts the presence of gallic and ellagic tannins, coumarins and saponins was observed from both plants and the presence of flavonoids, aglycones, sterols and triterpenes were only found in Combretum glutinosum. Maryam Bashir et al., 2015 studied about Conocarpus erectus which contains phenols such as flavonoids and tannins as major constituents. The extract from different parts (leaves, stems, fruits, and flowers) showed high antioxidant, anticancer and hepatoprotective activity due to the presence of phenolic compounds. Tannins have high antimicrobial activity than other phenolic compounds.

\section{ANTIOXIDATIVE ACTIVITY}

Antioxidation means opposite of oxidation. Oxidation is a word which is very essential in living organism for the acquirement of energy in catabolism. Oxidative damage is done by the free radical which may relate to aging and diseases such as atherosclerosis, cancer, diabetes and cirrhosis (Halliwell et al., 1999). Free radical is natural by products of human metabolism which can harm our body by attacking our cells and breaking our cellular membrane, reacting with the proteins, nucleic acids and enzymes present in the cells. These attacks by free radical are known as oxidative stress, which is capable for cell misfunctioning. They are produced by our body while using oxygen during respiration process and they are also generated by the environmental pollutants (Li et al., 1994). Nose et al., 2000 stated that there is a balance between quantity of free radicals generated in the body and the antioxidants defence system which scavenge these free radicals preventing them from deleterious effects in the body. But when there is increase in free radical due to environmental factors or by infection in our body it leads to oxidative stress (Finkel et al., 2000). So many plants have antioxidation properties which can be helpful for curing diseases. Zheng et al., 2001 and Cai et al., 2003 stated that fruits, medicinal herbs, vegetables, etc in plants may contain a wide variety of 
free radical having scavenging molecules such as phenolic acids, flavonoids, quinones, coumarins, lignans, stilbenes, tannins which are phenolic compounds; alkaloids, amines, betalains which are nitrogenous compounds; vitamins; terpenoids including carotenoids and some other endogenous metabolites which are ich in antioxidant activity. Owen et al., 2000; Sala et al., 2002 had studied about epidemiological studies which shows antioxidant compounds possess antitumor, antibacterial, antimutagenic, anti-inflammatory, anticarcinogenic, anti- atherosclerotic and antiviral activities to a greater or lesser extent. M.A. Aderogba et al., 2012 he studied that some species of Combretaceae family have antioxidant activities. Cheng et al., 2003 studied about species of Combretaceae family in which Terminalia chebula extract have different level of antioxidant activity for anti-superoxide radical formation, free radical scavenger activity and antiLPO. It is also used in the treatment of piles, fever, cough, vomiting, etc. Terminalia arjuna bark is used as a cardioprotective agent. The bark powder is used as antioxidant effect in humans by Gupta et al., 2001. Mabogo et al., 1990 concluded that in water extract of Terminalia sericea and Gunnera perpensa higher scavenging activity as compared to methanol extract. Bouchet et al., 1996 and in 1998 studied about Guiera senegalensis in which he showed that galloyl quinic acid is derived from the galls and have shown antioxidant activities. Martini et al., 2004 showed that Combretum erythrophyllum possess antioxidant compound named 5-hydroxy-7,4'-dimethoxyflavone and synthetic chemicals such as phenolic compounds have strong radical scavenger effect (Imaida et al., 1983). Blois et al., 1958 also reported antioxidant activity of methanol extract of aerial parts of Combretum ovalifolium. M.A. Aderogba et al., 2012 studied about Isolation of antioxidant constituents from Combretum apiculatum subsp. apiculatum in that he had isolated four antioxidant compounds from the leaves and structures of this compounds were determined by spectral analysis.
P. Masoko et al., 2007 had studied screening of twenty-four south african Combretum and six terminalia species (Combretaceae) for antioxidant activities. In that he concluded that in TLC-DPPH screening method Combretum hereroense having 16 and Combretum collinum ssp. Taborense having 10 prominent antioxidant compound followed by 22 other combretum they are Combretum celastroides ssp. celastroides, Combretum celastroides ssp. orientale , Combretum imberbe, Combretum padoides, Combretum caffrum, Combretum erythrophyllum, Combretum kraussii, Combretum woodii, Combretum collinum ssp. Suluense, Combretum zeyheri, Combretum albopunctatum, Combretum apiculatum ssp. Apiculatum, Combretum edwardsii, Combretum moggi, Combretum mole, Combretum petrophilum, Combretum microphyllum, Combretum paniculatum, Combretum bracteosum, Combretum mossambicense, Combretum acutifolium and Combretum nelsonii. Acetone extracts of all tested Combretum species had 53 active bands and methanol had 55. All Terminalia species extracted with acetone and methanol had antioxidant activity. Terminali gazensis and Terminalia mollis methanol extracts had 11 and 14 active compounds respectively in one of the solvent systems used. The qualitative DPPH assay on TLC was successfully used in this study to systematically assess the total antioxidant activity of the Combretum and Terminalia species extracts. Terminalia prunioides M.A.Lawson , Terminalia brachystemma Welw. ex Hiern , Terminalia sericea Burch ex DC , Terminalia gazensis Bak.f. , Terminalia mollis Laws and Terminalia sambesiaca Engl.\&Diels are 6 terminalia species from which Terminalia gazensis and Terminalia mollis have most prominent antioxidant compounds in methanol extracts having 11 and 14 active compounds in them and they concluded that to study antioxidant activity qualitative DPPH assay on TLC was successfully used in Combretum and Terminalia species. Sunita Bhatnagar et al., 2012 studied that Combretum roxburghii is positive for antioxidant 
activity and in all the three solvent (hexane, DCM and chloroform) 27 bands of antioxidant are found.

\section{v. CONCLUSION}

This study revealed that species of Combretaceae family are widely used traditionally for treating hepatitis, malaria, respiratory infections, and cancer. They also have anti scavenger activity, antimicrobial and anti-cancerous activity and main objective was to review species of Combretaceae family having important secondary metabolite, having antioxidant activity with medicinal uses which can be help in future for further analysis. This study provides information of 11 medicinal plants, 9 phytochemical containing plants and 33 plants having antioxidant activity. To be quite optimistic that this review article will surely stimulate present day researcher to undertake more systematic research work on this important species of Combretaceae family so as to isolate more phytochemicals showing antioxidant activities having medicinal uses and to discover other significant biological activities of the plants.

\section{REFERENCES}

[1]. Mann, Y. Yahaya, A. Banso and F. (2008). John Phytochemical and antimicrobial activity of Terminalia avicennioides extracts against some bacteria pathogens associated with patients suffering from complicated respiratory tract diseases. Journal of Medicinal Plants Research Vol. 2(5), pp. 094-097.

[2]. Aliyu AB, Musa AM, Abdullahi MS, Oyewale AO, Gwarzo US. (2008). Activity of plant extracts used in northern Nigerian traditional medicine against methicillin resistant Staphylococcus aureus (MRSA). Niger J Pharm Sci 7: 1-8.

[3]. Amadou Dawe, Saotoing Pierre, David Emery Tsala and Solomon Habtemariam. (2013). Phytochemical Constituents of Combretum
Loefl. (Combretaceae). Pharmaceutical Crops,2, 4, 38-59.

[4]. Bokhad M. N and Rothe S. P. (2012). Preliminary phytochemical investigation of Combretum albidum G. Don; An ignored medicinally important liana. Journal of Experimental Sciences 2012, 3(3): 01-04 ISSN: 2218-1768.

[5]. Bouquet U, Debray A. (1974). The Useful Plants of west Tropical Africa. Grown agent for Oversea Government and administration, London. 28: 53, 415.

[6]. Buren JPV, Robinson WB. (1969). Formation of complexes between protein and tannin acid J Agri Food Chem 17: 772-777.

[7]. Burkill, H.M. (2000). The useful plants of West Tropical Africa. 2nd edition. Volume 5, Families S-Z, Addenda. Royal Botanic gardens, kew, Richmond, United Kingdom. 686pp.

[8]. C. K. Kokate. (1994). Practical Pharmacognosy, Vallabh Prakashan, New Delhi, India, 1994.

[9]. C. O. Ujowundu, O. E. Okafor, N. C. Agha, L. A. Nwaogu, K. O. Igwe and C. U. Igwe. (2010). Phytochemical and chemical composition of Combretum zenkeri leaves Journal of Medicinal Plants Research Vol. 4(10), pp. 965-968.

[10]. Cho E, Seddom J, Ronser B, Willet W, Hankinson S. (2004). Prospective study of intake of fruits, Vegetables, Vitamins and carotenids and related muscucopathy. Arch. Opthalmol. 122: 883- 892.

[11]. Ciulei, I. (1982). Methodology for analysis of vegetable drug. Ministry of Chemical Industry, Bucarest, 67pp.

[12]. Coulibaly k., zirihi g., guessennd-kouadio $n$, oussou k., dosso m. (2014). Antibacterial properties studies of trunk barks of terminalia ivorensis (Combretaceae), a commercial and medicinal specie, on some methicillin-resistant Staphylococci spp strains, African Health Sciences Vol 14 Issue 3, 753- 756. 
[13]. Cowan M. M. (1999). Plant pruducts as antimicrobial agents. Clinic. Microbial. Rev., 1999; 12, pp. 564-582.

[14]. Duke, J. A. and Wain, K. K. (1981). Medicinal plants of the World: Computer index with more than 85,000 entries. 3, 1654 .

[15]. Edeoga HO, Okwu DE, Mbacble BO. (2005). Phytochemical constituents of some Nigerian medicinal plants. Afr. J. Biotechnol. 4(7): 685688.

[16]. Eloff, J.N. (1999b). It is possible to use herbarium specimens to screen for antibacterial components in some plants. Journal of Ethnopharmacology 67, 355-360.

[17]. Eloff, J.N., McGaw, L.J., (2006). Plant extracts used to manage bacterial, fungal and parasitic infections in Southern Africa. In: Ahmad, I. (Ed.), Modern Phytomedicine: Turning Medicinal Plants into Drugs. Wiley-VCH, Germany, pp. 97-121.

[18]. G.Shivapriya, S. Bhagavathy, P.Arumugam. (2019). In vitro cytotoxic activity of methanolic extract of Combretum ovalifolium against MCF7 Cancer cell lines. International Journal of Scientific Development and Research (IJSDR), Volume 4, Issue 9, 117-122.

[19]. Gedson Rodrigues de Morais Lima, Igor Rafael Praxedes de Sales, Marcelo Ricardo Dutra Caldas Filho, Neyres Zínia Taveira de Jesus, Heloina de Sousa Falcão, José Maria BarbosaFilho, Analúcia Guedes Silveira Cabral, Augusto Lopes Souto, Josean Fechine Tavares and Leônia Maria Batista. (2012). Bioactivities of the Genus Combretum (Combretaceae):

Review,Molecules 2012, 17, 9142-9206.

[20]. Harborne JB. (2005). Phytochemical methods-A guide to modern techniques of plant analysis. Springer Pvt Ltd.

[21]. Hills AF. (1952). Economic Botany. A textbook of Useful Plants and plant products. 2nd Mc Graw Hilll Book Company Inc., New York p. 91.
[22]. Hutching, A.; Scott, A.H.; Lewis, G.; Cunningham, A.B. Zulu. (1996). Medicinal Plants-An Inventory; University of Natal Press, Pietermaritzburg, South Africa, pp. 27-41.

[23]. Irvine, F. R. (1961). Woody plants of Ghana with special reference to their uses. Oxford University Press, London, pp 868.

[24]. J. B. Harborne. (1998). Phytochemical Methods, Chapman \& Hall, London, UK, 1998.

[25]. Karthikumar S, Vigneswari K, Jegatheesan K. (2007). Screening of antibacterial and antioxidant activities of leaves Eclipta prostrate (L). Sci. Res. Essay. 2(4): 101-104.

[26]. Kerharo, J. \& Adam, J.G. (1974). La pharmacopée sénégalaise traditionnelle. Plantes médicinales et toxiques. Vifot \& Frères, Paris, France. 1011pp.

[27]. M. M. Cowan. (1999). Plant products as antimicrobial agents. Clinical Microbiology Reviews, vol. 12, no. 4, pp. 564-582.

[28]. M.A. Aderogba , D.T. Kgatle, L.J. McGaw, J.N. Eloff. (2012). Isolation of antioxidant constituents from Combretum apiculatum subsp. Apiculatum. South African Journal of Botany 79, 125-131.

[29]. Mangoyi R, Mafukidze W, Marobela K, Mukanganyama S. (2012). Antifungal Activities and Preliminary Phytochemical Investigation of Combretum Species from Zimbabwe. J Microbial Biochem Technol 4: 037-044.

[30]. Mangoyi R, Mukanganyama S. (2011). In Vitro Antifungal Activities of Selected Medicinal Plants from Zimbabwe against Candida albicans and Candida krusei. African J Plant Sci Biotech 8-14.

[31]. Martini, N. D., Katerere, D. R. P., \& Eloff, J. N. (2004). Biological activity of five antibacterial flavonoids from Combretum erythrophyllum (Combretaceae). Journal of ethnopharmacology, 93(2-3), 207-212.

[32]. Martini, N.D., Eloff, J.N. (1998). The preliminary isolation and of several 
antibacterial compounds from Combretum erythrophyllum (Combretaceae). Journal of Ethnopharmacology 62, 255-263.

[33]. Maryam Bashir1, Muhammad Uzair1, Bashir Ahmad Chaudhry. (2015). A review of phytochemical and biological studies on Conocarpus erectus (Combretaceae). Pakistan journal of Pharmaceutical research, Vol 01, 1-8.

[34]. Masoko P, Eloff JN. (2006). Bioautography indicates the multiplicity of antifungal compounds from twenty-four southern African Combretum species (Combretaceae). Afr J Biotech 5: 1625-1647.

[35]. McGaw, L.J., Rabe, T., Sparg, S.G., Jäger, A.K., Eloff, J.N., Van Staden, J. (2001). An investigation of the biological activity of Combretum species. Journal of Ethnopharmacology 75, 45-50.

[36]. Morton, J. F. (1981). Atlas of Medicinal Plants of Middle America, Bahamas to Yucatan. Charles C. Thomas, Springfield, Illinois, 78-80.

[37]. Nacoulma, O.G. (1996). Plantes médicinales et pratiques médicales traditionnelles au Burkina Faso. Cas du plateau central. Thèse d'état. Université de Ouagadougou, Tome I, 320pp, Tome II, 261pp.

[38]. Obadoni BO, Ochuko PO. (2001). Phytochemical studies and comparative efficacy of the crude extracts of some Homostatic plants in Edo and Delta States of Nigeria. Global J Pure Appl Sci 8: 203-208.

[39]. Owoyele BY, Olayele SB, Elegba RA. (2002). Anti-inflammatory and Analgesic Activities of leaf Extract of Landolphia oweriensis. Afr. J. Biomed. Res. 4(3): 131-133.

[40]. Serage, S.A. (2003). Isolation and characterization of antibacterial compounds in Combretum apiculatum Sond. subsp. apiculatum. MSc Thesis. University of Pretoria.

[41]. Sore Harouna, Hilou Adama, Sombie Pierre Alexandre Eric Djifaby, Compaore Moussa, Meda Roland, Millogo Jeanne And Nacoulma
Odile Germaine. (2012). Phytochemistry and Biological Activities of Extracts from Two Combretaceae Found in Burkina Faso:Anogeissus Leiocarpus (DC) Guill. and Perr. And Combretum Glutinosum Perr. Ex DC. Universal Journal of Environmental Research and Technology, 383-392.

[42]. Soulsby EJ. (2005). Resistance to antimicrobials in humans and animals. British Journal of Medicine 331: 1219-1220.

[43]. Sreedhar, S., Nitha, B., \& Shree, A. R. (2013). Antimicrobial activity of stem bark of Combretum albidum G. Don; a traditional medicinal liana. International Journal of Pharmaceutical Sciences and Research, 4(8), 3184.

[44]. Thomas DT. (1974). The useful plants of West Africa. J. Ethnopharmacol. 105(1): 12-30.

[45]. Umar K.J, Hassan L.G, Dangoggo S.M, Inuwa M, Almustapha M.N. (2007). Nutritional Content of Melochia corchorifolia (Linn.) Leaves. International Journal of Biological Chemistry, 1 (4): 250-255.

[46]. Ygor Lucena Cabral de Oliveira, Lu'ıs Cl'audio Nascimento da Silva, Alexandre Gomes da Silva, Alexandre Jos'eMacedo, JaneteMagali de Ara ' ujo, Maria Tereza dos Santos Correia, and M'arcia Vanusa da Silva. (2012). Antimicrobial Activity and Phytochemical Screening of Buchenavia tetraphylla (Aubl.) R. A. Howard (Combretaceae: Combretoideae). The Scientific World Journal Volume, Article ID 849302, 1-6.

\section{Cite this article as :}

Christian Stacey, Bharat Maitreya, "A Review : On Phytochemical Analysis and Antioxidant activities with Medicinal uses of Combretaceae Family", International Journal of Scientific Research in Science and Technology (IJSRST), Online ISSN : 2395-602X, Print ISSN : 2395-6011, Volume 8 Issue 2, pp. 287-294, March-April 2021. Available at doi : https://doi.org/10.32628/IJSRST218244

Journal URL : https://ijsrst.com/IJSRST218244 